\title{
Impact of Strategic Human Resource Practice on Corporate Performance in Selected Nigerian Banks
}

\author{
Stratejik Insan Kaynakları Uygulamalarının Nijerya'daki Bankaların Kurumsal \\ Performansı Üzerine Etkisi
}

Olu OJO'

\begin{abstract}
This study examines whether there is any relationship between strategic human resource practice and corporate performance in the Nigerian banking industry. It is against this background that this study tries to look at the following objectives: (i) to determine if strategic human resource practice enhances corporate performance; (ii) to investigate the extent of relationship between strategic human resources practices and financial performance. In order to address the above research objectives, the following research questions are advanced: (i) Does a strategic human resource practice enhance corporate performance? (ii) What is the nature of relationship between strategic human resources practices and corporate financial performance? Two hypotheses were formulated and tested in this research.

Primary data were garnered, presented and analysed for this study. Data collected through questionnaire were presented with the help of frequency tables and percentages; while data analysis was done using Statistical Package for Social Sciences (SPSS). This study found that there is positive relationship between strategic human resource practice and corporate performance of organisation.
\end{abstract}

Keywords: Human resource, corporate performance, strategic management, organisation

\section{INTRODUCTION}

Strategic human resource practice is a function of the level of organisation performance. This study tries to see the link that exists between strategic human resource practice and corporate performance. Cascio (1991) and Flamholtz (1985) argued that the financial returns associated with investment in progressive human resource management practices are generally substantial. Therefore, in exploring the link between strategic human resources practices and corporate performance, it is paramount to note that the determinants of this studies is the general organisational performance in relation to productivity and growth that results from effective strategic
ÖZET

Bu çalışma Nijerya bankacılık sektöründe, stratejik insan kaynakları uygulamaları ile kurumsal performans arasında ilişki olup olmadığını incelemektedir. Buna dayanarak çalışmanın amaçları şöyledir: (i) stratejik insan kaynakları uygulamasının kurumsal performansı arttırıp arttırmadığını ortaya koymak; (ii) stratejik insan kaynakları uygulaması ile finansal performans arasındaki ilişkinin derecesini araştırmak. Bu amaçlar doğrultusunda geliştirilen araştırma soruları ise şunlardır: (i) Stratejik insan kaynakları uygulaması kurumsal performansı arttıır mı? (ii) Stratejik insan kaynakları uygulaması ile finansal performans arasındaki ilişkinin niteliği nedir? Birincil kaynaktan toplanan verilerin analiz edilerek sunulduğu çalışmada iki hipotez geliştirilmiş ve test edilmiştir. Anket yolu ile toplanan veriler frekans tabloları ve yüzdeler ile sunulmuş, veri analizi SPSS paket program ile gerçekleştirilmiştir. Çalışmada sonuç olarak bir örgütte stratejik insan kaynakları uygulamaları ile kurumsal performans arasında pozitif bir ilişki olduğu saptanmıştır.

Anahtar Kelimeler: Insan kaynakları, kurumsal performans, stratejik yönetim, örgüt

human resource management.

This study becomes important because of the strategic position of employees in the actualisation of organisation's goals and objectives. Human resource department and programme have become an element of the firm's profit equation to be minimised as a cost and maximised as a value-adding component of firm strategy. Consequently, human resource practitioners have become anxious with demonstrating the value of the human resource function, particularly through showing its impact on firm performance (Pfeffer, 1997; Ulrich, 1997). Fuelled by these practitioners' concern, recent academic research has attempted to demonstrate the impact of human re- 
source management practice on firm performance.

A number of studies have been carried out on the impact of strategic human resources practices and corporate financial performance. In fact, academic interest in showing human resource's impact on firm performance is evidenced by the fact that some academic journals have devoted special issues to research establishing this linkage. First attempts at empirical linkage looked in the areas of Human Resource practices such as training (Russel, Terborg and Powers, 1985), appraisals (Borman, 1991), and compensation (Milkovich, 1992) to firm performance. Thus, both research and practice have seen an increasing concern with linking human resource practice to the firm's performance. In spite of this emphasis, current research did not provide sufficient justification for the link between human resource and firm performance. While majority of the published studies do show significant relationships between human resource and firm performance, these relationships are neither universal nor consistent (Becker and Gerhart, 1996). The empirical evidences emerging from various studies about the effect of human resource management on corporate financial performance have so far yielded mixed results that are inconclusive and contradictory. Because of these contradictory results the relationship between human resource management practice and corporate performance is controversial.

Thus, the question of whether strategic human resource practices improves or worsens firm financial performance is stills worthy of further research such as the one being undertaken in this study. Besides, the impact of strategic human resource practice on firm performance has not received adequate research attention in Nigeria. Research also shows most of the studies on impact of strategic human resource practice on corporate performance that have been reported were carried out on industrialised countries such as the United States (Martell and Caroll, 1995), United Kingdom, Australia and Asia (Purcell, 2002 and 2004; Storey, 1995 and Legge, 1995) among others. This means that there is a major gap in the relevant literature on developing countries including Nigeria, which has to be covered by research. This research attempts to fill this gap by studying the situation of the Nigerian banking industry and providing more empirical evidence on the effects of strategic human resource practices on corporate performance.

It is against this background that this study tries to look at the following objectives: (i) to determine if strategic human resource practice enhances corporate performance; (ii) to investigate the extent of relationship between strategic human resources practices and financial performance. In order to address the above research objectives, the following research questions are advanced: (i) Does a strategic human resource practice enhances corporate performance? (ii) What is the nature of relationship between strategic human resources practices and corporate financial performance? The study found that there is obvious link between strategic human resource practice and corporate performance. That strategic human resource enhances corporate performance

\section{LITERATURE REVIEW}

Human resource management practice is a relatively undeveloped field, which has undergone a rapid growth. From its early roots as the function involved in the administrative aspects of hiring, firing, and payroll, it has seen stages where union relations, employee satisfaction, and legal compliance have served as dominant areas of emphasis and expertise. Strategic human resource practice emphasises the need for human resource plans and strategies to be formulated within the context of overall organisational strategies and objectives, and to be responsive to the changing nature of the organisation's external environment. Most recently a trend has developed toward justifying the expenditures for and existence of the Human Resources function. Human Resource departments and programs have become an element of the firm's profit equation to be minimized as a cost and maximized as a value-adding component of firm strategy. Thus the overall themes of Strategic Human Resource Management (SHRM) are the integration of all Human Resource practice functions, adherence to broad organisational goals and responsiveness to the external environment.

Wright and McMahan (1992) define strategic human resource practice as "the pattern of planned human resource deployments and activities intended to enable the firm to achieve its goals." Clearly reveals by this definition is that the critical goal of strategic human resource practice is to contribute to organisational performance in achieving corporate goals and objectives.

\subsection{Strategy and Human Resource Management}

It is helpful to first of all focus on organisation strategy since the meaning of this term is more thoroughly explored within the literature. Boxall and 
Purcell (2003) argue that it is possible to find strategy in every organisation because it is embedded in the important choice managers and staff of the firm make about what to do. It is referred to by them as strategic choice or as the strategies firms adopt in dealing with strategic problems. A further dimension to this is that strategy is directed towards either maintaining viability of the organisation or producing sustained advantage in the markets in which the organisation exists.

A key issue to be resolved is how human resource practice plays and influencing the direction and shape of the evolving strategy. Further, if human resource practice is considered an integral part of the process of strategic choice, how is its influence affected? As with company strategy, it might be that strategic human resource practice is seen as contributing to strategic choice within the organisation by either maintaining viability or producing a sustained advantage. So, strategic Human Resource practice emphasises the need for human resource plans and strategies to be formulated within the context of overall organisational strategies and objectives, and to be responsive to the changing nature of the organisation's external environment. It is a model, which likes all models, requires interpretation and adaptation by practitioners to ensure the most suitable fit between human resource and business strategies and plans. Thus the overall themes of Strategic Human Resource Management (SHRM) are the integration of all human resource practice functions, adherence to broad organisational goals and responsiveness to the external environment. The term strategy is used to explain both the processes (organisational restructuring) and the outcomes (market position) of chosen long-term directions. It can be either a conscious planned activity or a series of events, which lead to a desirable outcome. As discussed above, strategic human resource practice is concerned with ensuring a strategic "alignment" or fit between company and human resource practice strategies. It necessarily involves an evaluation of the likely impact of both the external and internal organisational environment, the long term goals of the organisation and the ways in which human resource practice strategy will enable the adaptation of human resource towards these goals.

Nankervis, Compton and the Bairb (2005) identify three types of linkages between human resource and organisational strategies. Firstly, there is the accommodative type. Here a human resource strategy simply follows organisational strategies, accommo- dating the staffing needs of already chosen company strategies. So strategic in this sense is for human resource practice to follow the organisation's strategy. Second, there is the interactive type. It is characterised as a two way communication process between human resource practice and corporate planning in which human resource practice contributes to, and then reacts to, overall strategies. For this type, strategic human resource practice asserts that Human resource practice is an active contributor to strategy development and execution. Third, there is the type known as fully integrated. For this type the human resource specialist is intimately involved in the overall strategic process in both formal and informal Interactions, a real reflection of strategic human resource management in practice (Nankervis et al, 2005). The degree of involvement will extend to human resource management being fully represented the senior management group level and human resource actively participating in strategic decisions and it might even involve a human resource manager's to the Board of Directors.

\subsection{Organisational Performance and Strategic Human Resource Management}

Within the field of Strategic Human Resource practice, Dyer and Reeves (1995), in their review of research on the efficacy of "bundling" Human Resource practices, proposed four possible types of measurement for organizational performance: 1) Human Resource outcomes (turnover, absenteeism, job satisfaction), 2) organizational outcomes (productivity, quality, service), 3) financial accounting outcomes (ROA, profitability), and 4) capital market outcomes, (stock price, growth, returns). They proposed that Human Resource strategies were most likely to directly impact human resource outcomes, followed by organizational, financial, and capital market outcomes. This stemmed both from the facts that Human Resource strategies are primarily designed to impact Human Resource outcomes, and that the increasing complexity of factors which influence higher level outcomes would diminish the relative contribution of Human Resource factors to those outcomes. They suggested these facts, coupled with the reality that human resource outcomes are deficient from the standpoint of most executives might explain why most of the strategic Human Resource research has focused on organizational outcomes rather than the other three.

Note that implicit in this model, as well as others (e.g. Huselid, 1995) is the basic idea that outcomes 
can be differentiated at hierarchical levels, with outcomes at one level contributing to outcomes at the next level. While each model differs in the number of levels and the exact outcomes, a generic form of the model is that HR practices have their most direct impact on Human Resource outcomes, which in turn, contribute to higher level organizational performance constructs.

The following section presents a detailed examination of the types of measures of firm performance that have been used in strategic Human Resource practice research. By reviewing the measures used, we sought to answer 3 basic questions: (1) What kinds of measures are being used, (2) are the types of measures systematically related to aspects of the research such as the level of analysis or source of the information, and (3) what control variables seem to be most often used in this research. We also sought to clarify some of the tacit assumptions that colour thinking about organizational performance in hopes of shifting the research focus from where there may be the most current research light to where there is the greatest need for further empirical illumination.

\section{HYPOTHESES OF THE STUDY}

The following are the hypotheses deduced for this research work.

\section{Hypothesis 1}

H0: Strategic human resource practices do not enhance corporate performance.

$\mathrm{H} 1$ : Strategic human resource practices enhance corporate performance.

\section{Hypothesis 2}

HO: There is no positive relationship between strategic human resource practice and corporate performance.

$\mathrm{H} 1$ : There is positive relationship between strategic human resource practice and corporate performance.

\section{METHODOLOGY}

This section focuses on the research techniques adopted and used for this study with the aim of achieving the research objectives. In this study, survey research design was adopted. Survey research design was chosen because the sampled elements and the variables that are being studied are simply being observed as they are without making any attempt to control or manipulate them.

The theoretical population of the study consists of the entire workers of the banks in Lagos State, Nigeria. The choice of Lagos State stems from the fact that the Headquarter Offices of Nigerian banks are located in Lagos State and that there is concentration of banks in Lagos State with over 25 percent of the branches of these banks are found in Lagos State alone. For effective coverage and lower cost, stratified sampling technique was used to select the participating banks. Nigerian banks were stratified into two strata based on the year they were established. Thus we have 'old' generation banks and 'new' generation banks. Two banks were selected from each stratum. Employees in selected banks were divided into three strata: management staff, senior staff, and junior staff. A simple random sampling technique was used to select a total of 120 employees that constituted our sample size. It should be pointed out that limited financial resources at the researcher's disposal could not permit or allow for a greater sample size. Every research work has a framework for collecting data. Its function is to ensure that the required data are collected accurately and economically. Primary method of data collection was used in this study. The primary data consists of a number of items in structured questionnaire that was administered to the respondents. The decision to structure the questionnaire is predicated on the need to reduce variability in the meanings possessed by the questions as a way of ensuring comparability of responses. The questionnaire was titled "Impact of Strategic Human Resource Practice on Corporate Performance: The Case of Nigerian Banks." However, only 106 out of 120 respondents returned their questionnaire and were used for final analysis in this study. This shows a respondent rate of $88.3 \%$.

One important way of ensuring that we have used the right instrument and have taken correct measurement is that our outcome must be in consonance with two major criteria for measuring quality known as validity and reliability (Ojo, 2003). To ensure the validity and reliability of the questionnaire used for the study, even number of experts were consulted to look at the questionnaire items in relation to its ability to achieve the stated objectives of the research, level of coverage, comprehensibility, logicality and suitability for prospective respondents. A pilot test which took the form of test-retest method was conducted at the branches of selected banks in Sango-Ota, Ogun State where 10 workers from each of the bank branches were selected using purposive random sampling technique. The choice of Sango-Ota for the pilot study was informed by the 
Table 1: Sex Distribution of Respondents

\begin{tabular}{ccc}
\hline Variables & Frequency & Percent \\
\hline Male & 58 & 54.7 \\
Female & 48 & 45.3 \\
Total & $\mathbf{1 0 6}$ & $\mathbf{1 0 0}$ \\
\hline
\end{tabular}

Source (Field Survey, 2009)

Table 2: Educational Qualifications of Respondents

\begin{tabular}{ccc}
\hline Variables & Frequency & Percent \\
\hline WASC O/L & 10 & 9.4 \\
NCE/ OND & 30 & 28.3 \\
HND/ B.SC & 35 & 33.0 \\
MBA, M.SC & 12 & 11.3 \\
OTHERS & 4 & 3.8 \\
Total & $\mathbf{1 0 6}$ & $\mathbf{1 0 0}$ \\
\hline
\end{tabular}

Source (Field Survey, 2009)

Table 3: Corporate Performance is Largely Determine by Strategic Human Resource Practice

\begin{tabular}{ccc}
\hline Variables & Frequency & Percent \\
\hline Strongly Agree & 53 & 50.0 \\
Agree & 43 & 40.6 \\
Undecided & 6 & 5.7 \\
Disagree & 4 & 3.8 \\
Strongly Disagree & 0 & 0 \\
Total & $\mathbf{1 0 6}$ & $\mathbf{1 0 0}$ \\
\hline
\end{tabular}

Source (Field Survey, 2009)

Table 4: Effective Reward of Human Resource Leads to Superior Corporate Performance

\begin{tabular}{ccc}
\hline Variables & Frequency & Percent \\
\hline Strongly Agree & 46 & 43.4 \\
Agree & 40 & 37.7 \\
Undecided & 10 & 9.4 \\
Disagree & 6 & 5.7 \\
Strongly Disagree & 4 & 3.8 \\
Total & $\mathbf{1 0 6}$ & $\mathbf{1 0 0}$ \\
\hline
\end{tabular}

Source (Field Survey, 2009)

Table 5: Strategic Human Resource Aids Corporate Financial Performance

\begin{tabular}{ccc}
\hline Variable & Frequency & Percent \\
\hline Strongly Agree & 52 & 49.0 \\
Agree & 48 & 45.3 \\
Undecided & 4 & 3.8 \\
Disagree & 2 & 1.9 \\
Strongly Disagree & 0 & 0 \\
Total & $\mathbf{1 0 6}$ & $\mathbf{1 0 0}$ \\
\hline
\end{tabular}

Source (Field Survey, 2009)

fact that it is the city where the researcher is living as at the time the study was conducted, with a fair concentration of the branches of the banks studied. Data collected from the questionnaire were analysed, summarised, and interpreted accordingly with the aid of 
Table 6: Strategic Human Resource Practice is Positively Related with Corporate Performance

\begin{tabular}{ccc}
\hline Variables & Frequency & Percent \\
\hline Strongly Agree & 37 & 34.9 \\
Agree & 59 & 55.7 \\
Undecided & 6 & 5.7 \\
Disagree & 4 & 3.3 \\
Strongly Disagree & 0 & 0 \\
Total & $\mathbf{1 0 6}$ & $\mathbf{1 0 0}$ \\
\hline
\end{tabular}

Source (Field Survey, 2009)

descriptive statistical techniques such as total score and simple percentage. Regression analysis was used to proof the level of significance in testing stated hypotheses.

\section{DATA PRESENTATION AND ANALYSIS}

This section deals with the presentation and analysis of data collected from the respondents through our research instrument.

The first data to be presented and analysed is based on the respondents' gender.

From Table 1 above it is evident that $54.7 \%$ of the respondents are male while $45.3 \%$ of the respondents are female. This shows that majority of our respondents are of the male sex.

Table 2 above shows that $9.4 \%$ of the respondents obtained West African School Certificate 'Ordinary Level', 28.3 \% obtained National Certificate of Education and National Diploma, 33.0\% obtained Higher National Diploma and Bachelor Degree, 11.3\% obtained Masters in Business Administration and other Masters Degree while the remaining 3.8\% of the respondents have other educational qualifications such as ACA, CIPMN, and CIS among others. From the above, we can infer that overwhelming majority of our respondents are well educated.

The above table reveals the respondents feedback on whether corporate performance is determined by strategic human resource management practice. 50\% of the respondents strongly agree with the statement. $40.6 \%$ of the respondents agree with the statement, $5.7 \%$ respondents are undecided with the statement. Only $3.8 \%$ of the respondents disagree with the statement while none of the respondents strongly disagree with the statement. From the above we can conclude that corporate performance is largely determined by strategic human resource management practice.

The next question deals with whether effective reward of human resource can lead to superior corporate performance.
Table 4 above expresses responses from the respondents about the impact of effective reward on corporate performance. $43.4 \%$ of the respondents strongly agree that effective reward of human resource leads to superior corporate performance. $37.7 \%$ of the respondents also agree with the statement. $9.4 \%$ of the respondents are undecided about the statement. $5.7 \%$ of the respondents disagree with the statement while the remaining $3.8 \%$ of the respondent strongly disagree with the statement. The conclusion that can be drawn from here is that effective reward of human resource leads to superior corporate performance.

In the above table, $49.0 \%$ of the respondents strongly agree that strategic human resource practice aids corporate financial performance. $45.3 \%$ of respondents agree with the above statement. 3.8\% of respondents are undecided about the statement while 1.9 of the respondents disagrees with the statement. However, none of the respondents strongly disagree that strategic human resource practice aids corporate financial performance. Consequently, we can conveniently say that strategic human resource aids corporate financial performance.

In the above table, the researcher sought to know the respondents view on whether strategic human resource practice is positively related with corporate performance. $34.9 \%$ of the respondents strongly agree with the statement. Overwhelming majority of the respondents, $55.8 \%$ agree with the statement. $5.7 \%$ of the respondents are undecided about the statement. Only $3.3 \%$ of the respondents disagree with the statement, while none of the respondents strongly disagree with the statement. Thus, we can conclude that strategic human resource practice is positively related with corporate performance.

\section{TESTING OF HYPOTHESES}

The hypotheses formulated in this study are tested with the use of regression statistics. The decisions reached on hypotheses are based on the results 
Model Summary (b)

\begin{tabular}{|l|l|l|l|l|}
\hline Model & R & R Square & Adjusted R Square & Standard Error of the Estimate \\
\hline 1 & $.325(\mathrm{a})$ & .105 & .097 & .612 \\
\hline
\end{tabular}

a Predictors: (Constant), strategic human resource do not determine corporate financial performance.

b Dependent Variable: sales growth is achieved through a good training policy.

ANOVA (b)

\begin{tabular}{|c|c|c|c|c|c|c|}
\hline Model & & Sum of Squares & $\mathrm{df}$ & Mean Square & $\mathrm{F}$ & Sig. \\
\hline 1 & Regression & 4.591 & 1 & 4.591 & 12.253 & $.001(a)$ \\
\hline & Residual & 38.969 & 104 & .375 & & \\
\hline & Total & 43.557 & 105 & & & \\
\hline
\end{tabular}

a Predictors: (Constant), strategic human resource do not determine corporate financial performance.

b Dependent Variable: sales growth is achieved through a good training policy

obtained both from the regression calculation and the tabulated value of the regression distribution.

If the computed value of regression is less than the critical value, the null hypotheses $(\mathrm{Ho})$ are accepted and the alternative hypotheses $(\mathrm{H} 1)$ rejected. But if the value of regression is greater than the critical value, the alternative hypotheses $(\mathrm{H} 1)$ are accepted and the null hypotheses ( $\mathrm{Ho}$ ) rejected.

\subsection{Hypothesis 1}

HO: Strategic human resource practices do not enhance corporate performance.

$\mathrm{H1}$ : Strategic human resource practices enhance corporate performance.

$R$ value $=.325(\mathrm{a})$ where, the $R=$ value shows that $32.50 \%$ of the dependent variable can be accounted for by the independent variable

$\mathrm{R}$ square value $=.105$ .001

The regression is therefore, very significant at

When the $F$ value is 12.253 the regression table shows $F$ value is to be 12.253 at .001 significant level which shows that the null hypothesis should rejected and the alternative hypothesis should be accepted as stated above.

\section{Decision}

Based on the analysis above for which all calculated values are above the critical values, the null hypothesis $(\mathrm{H} 0)$ is therefore, rejected while the alternative hypothesis $(\mathrm{H} 1)$ is accepted; which states that strategic human resource practices enhance corporate performance.

\subsection{Hypothesis 2}

HO: There is no positive relationship between strategic human resource practice and corporate performance.

$\mathrm{H} 1$ : There is positive relationship between strategic human resources practice corporate performance.

$\mathrm{R}$ value $=.399$ (a) where, the $\mathrm{R}=$ value shows that $39.9 \%$ of the dependent variable can be accounted for by the independent variable.

$\mathrm{R}$ square value $=.159$

Model Summary (b)

\begin{tabular}{|c|c|c|c|c|}
\hline Model & $\mathrm{R}$ & R Square & Adjusted R Square & Std. Error of the Estimate \\
\hline 1 & .399 (a) & .159 & .151 & .608 \\
\hline
\end{tabular}

a Predictors: (Constant), strategic human resource determine corporate financial performance.

b Dependent Variable: strategic human resource aid financial performance.

ANOVA (b)

\begin{tabular}{|l|l|r|r|r|r|r|}
\hline Model & & Sum of Squares & $\mathrm{df}$ & Mean Square & $\mathrm{F}$ & Sig. \\
\hline 1 & Regression & 7.277 & 1 & 7.277 & 19.679 & $.000(\mathrm{a})$ \\
\hline & Residual & 38.459 & 104 & .370 & & \\
\hline & Total & 45.736 & 105 & & & \\
\hline
\end{tabular}

a Predictors: (Constant), strategic human resource determine corporate financial performance.

b Dependent Variable: strategic human resource aid financial performance. 
The regression is therefore, very significant at $.000(a)$

When the $F$ value is 19.679 the regression table shows $F$ value is to be 19.679 at .000 significant level which shows that the null hypothesis should rejected and the alternative hypothesis should be accepted as stated above.

Decision

Based on the analysis above for which all calculated values are above the critical values, the null hypothesis $(\mathrm{HO})$ is therefore, rejected while the alternative hypothesis $(\mathrm{H} 1)$ is accepted; which states that Strategic Human Resources is positively related to financial performance.

\section{EMPIRICAL FINDINGS}

Based on analysed data, the findings in this study include the followings:

1. A large number of respondents (34.9\%) strongly agree that strategic human resource practice enhance corporate performance, while overwhelming majority of respondents (55.7\%) also said that strategic human resource practice enhances corporate performance. None of the respondents strongly disagree with the statement.

2. It was also discovered that there is a link between corporate performance and strategic human resource practices. We found that $49.0 \%$ of the respondents strongly agree that strategic human resource practice aids corporate performance. In addition, another $45.3 \%$ of the respondent also agree with the statement. This evidently proves that there is a link between corporate financial performance and strategic human resource practices in the organisation.

3. It was discovered that there is a positive relationship between strategic human resource practice and corporate performance. This is evident from the respondents' feedback in which overwhelming majority of them $(90.6 \%)$ affirmed that there is a positive relationship between strategic human resource and corporate performance.

4. Finally, we also discovered that Corporate Per- formance is Largely Determine by Strategic Human Resource Practice and that effective Reward of Human Resource Leads to Superior Corporate Performance

\subsection{Implications of Findings}

The implications of the findings focus on the following:

1. Every organisation with must strategically manage its human resource for maximum performance.

2. Corporate organisations should try as much as possible to make sure that their human resource adequately compensated, rewarded and motivated to enhance their performance which will translate to improvement in corporate performance.

3. Since there is a link between corporate performance and strategic human resource practices in the organisation, managers should take note on how to develop the human resource in the organisation. This will also enhance future performance of the organisation.

4. Finally, managers should be more concerned and ensure that human resource practice is strategic as it affects overall performance of the organisation.

\section{CONCLUSION}

In this study, we have examined the impact of strategic human resource practice in enhancing corporate performance and investigated the extent of relationship between strategic human resources practices and financial performance. It was discovered that strategic human resource practice enhances corporate performance. So also, we found that there is a link between corporate performance and strategic human resource practices and that a positive relationship exists between strategic human resource practice and corporate performance. On this note, we conclude that corporate performance is greatly determined by strategic human resource practice in the organisation and human resource practice also can not be effective without a good corporate financial plan in the organisation. That is why the link between corporate performance and strategic human resource practices in the organisation of utmost importance. 


\section{REFERENCES}

Becker, B. and Gerhart B. (1996) "The Impact of Human Resource Management on Organizational Performance: Progress and Prospects" Academy of Management Journal, 39(4):779-801.

Borman, W. C. (1991) "Job Behavior, Performance, and Effectiveness" M. D. Dunnette and \& L. M. Hough (eds.), Handbook of Industrial and Organizational Psychology, pp. 271-326.

Boxall, P. and Purcell, J. (2003) Strategy and Human Resource Management, Hampshire, Palgrave Macmillan.

Cascio, W. F. (1991) Costing Human Resource: The Financial Impact of Behaviour in Organization, 3rd Edition, Boston, PWS-Kent.

Dyer, L., and Reeves, T. (1995) "Human Resource Strategies and Firm Performance: What Do We Know and Where Do We Need To Go?” Paper Presented at The 10th World Congress of The International Industrial Relations Association, Washington, DC, Pearson.

Flamholtz, E. G. (1985) Human Resource Accounting, 2nd Edition, San Francisco, Jossey-Bass.

Huselid, M. (1995) “The Impact of HRM Practices on Turnover, Productivity and Corporate GF Financial Performance" Academy of Management Journal, 38(3):635-673.

Legge, K. (1995) Human Resource Management: Rhetoric's and Realities, London: Macmillan.

Martell, K. and Carroll, S. (1995) "How Strategic is Human Resource Management?" Human Resource Management, 34(2):253-267.
Nankervis, A., Compton, R. and Baird M. (2005) Human Resource Management, Australia, Nelson Publishing.

Milkovich, G. (1992) "Strengthening the Pay Performance Relationship", Compensation and Benefits Review, 24(6): 53-62.

Ojo, O. (2003) Fundamentals of Research Methods, Lagos, Standard Publications.

Pfeffer, J. (1997) The Human Equation: Building Profit by Pulling People First, Boston, HBS Press.

Purcell, J. (2002) Sustaining the HR and Performance Link in Difficult Times, CIPD Conference, Australia, Harrogate.

Purcell, J. (2004) Business Strategies and Human Resource Management: Uneasy Bedfellows or Strategic Partners? London, Bath University.

Russel, J. S., Terborg, J. R. and Powers, M. L. (1985) “Organizational Performance and Organizational Level Training and Support" Personnel Psychology, 38(4): 849-863.

Storey, J. (1995) Human Resource Management: A Critical Text, London: Routledge.

Ulrich, D. (1997) "Measuring Human Resources: An Overview of Practice and A Prescription for Results" Human Resource Management, 36(3): 303-315.

Wright, P. M., and Mcmahan, G. C. (1992) “Theoretical Perspectives for Strategic Human Resource Management” Journal of Management, 18(2): 295-320 